\title{
Amido Black 10B Dye Copper Complex-Synthesis, Characterization and Color Analysis
}

\author{
MARIA ELENA RADULESCU-GRAD ${ }^{1}$, GABRIELA VLASE ${ }^{2 *}$, GHEORGHE ILIA ${ }^{1,2}$, \\ ADELINA ANDELESCU1 ${ }^{1}$, SIMONA POPA ${ }^{3 *}$ (Đ https://orcid.org/0000-0002-7397-7715), \\ ALFA-XENIA LUPEA ${ }^{1}$ \\ ${ }^{1}$ Institute of Chemistry "Coriolan Dragulescu" 24 Mihai Viteazu Blvd., 300223, Timisoara, Romania \\ ${ }^{2}$ West University of Timisoara, Faculty of Chemistry-Biology-Geography, 15 Pestalozzi Blvd., 300115, Timisoara, \\ Romania \\ ${ }^{3}$ Politehnica University of Timisoara, Faculty of Industrial Chemistry and Environmental Engineering, 6 Vasile Parvan \\ Blvd., 300223, Timisoara, Romania
}

\begin{abstract}
The present paper presents the obtaining and the characterization of a new complex acid dye by combining the transition metal $C u$ (II) with an azo acid dye, namely Amido Black $10 B$ (C.I. 20.470), as ligand. The ligand and the resulted new azo complex were characterized by FT/IR spectroscopy, UV-Vis spectroscopy, AAs spectrometry, thermal analysis, and PXRD spectrometry. The structure of the ligand and the structure of the new synthesized copper complex were elucidated by all the above mentioned analysis methods. The formation of the azo metal complex with $\mathrm{Cu}(\mathrm{II})$ was confirmed by UV-Vis spectrum. Thermogravimetric and spectral analysis reveal its different stability in the air and nitrogen atmosphere, with high nitrogen stability. The PXRD analysis shows crystalline structure for the copper complex. At the same time, the color analysis was performed for the ligand and the synthesized complex in powder by means of UV-Vis CIEL*a*b* color space parameters, under the CIE recommended illuminants: D65 (natural day light), A (incandescent light) and F2 (fluorescent light) under the standard $10^{\circ}$ observer angle. An important color phenomenon, namely metamerism, was highlighted for the complex, as well. Due to the presence of the Cu (II) ions, this azo complex presents a different color, calculated by the color differences $\Delta E^{*}{ }_{a b}$ and $\Delta C^{*}$, a superior saturation and color strength than its ligand.
\end{abstract}

Keywords: metal complex dyes, thermal analysis, UV-Vis; PXRD, color analysis

\section{Introduction}

The azo chemical compounds are still in the attention of the scientific research, especially the azo dyes, a class of synthetic, colored organic compounds, which contain one or more azo bonds $(-\mathrm{N}=\mathrm{N}-)$, is mentioned [1,2]. These azo groups form bridges between organic residues, of which at least one is usually an aromatic nucleus. In principle, the manufacture of azo dyes is always based on the coupling of diazonium compounds with phenols, naphthols, arylamines, pyrazolones or other suitable components to give hydroxyazo, aminoazo compounds or their tautomers. The chemistry of these dyes varies from simple monoazo compounds to complex polyazo structures with molecular weights of 2000 or more [3]. The azo dyes are the most important class of organic dyes, due to the extended areas of use, such are: different industries (textile, coating, polymer, photography, printing and ceramic), optical fields (lasers, optical sensors, photochromic materials), nearly all foods and cosmetics, medicine (pharmaceutical products, photodynamic therapy, antimicrobial activity) etc. [4-8]. Generally, metal complex of azo dyes are formed from the reaction of transition metal ions with ligands in which the ortho positions adjacent to the azo group contain groups capable of coordinating with metal ions. The suitable groups are hydroxyl $(-\mathrm{OH})$ carboxy $(-\mathrm{COOH})$ amino (-NHR) and oxy-

*email: simona.popa@upt.ro 
acetic $\left(-\mathrm{OCH}_{2} \mathrm{COOH}\right)$ groups. The most used transition metals to form metal complex azo dyes used in textile dyeing are $\mathrm{Cu}, \mathrm{Co}$ and $\mathrm{Cr}[9,10]$. These compounds represent a well known class of dyes, due to their excellent light and wash fastness on substrates [11]. In fact, metal complex dyes belong to numerous classes of organic dyes such are direct, acid, and reactive dyes. The coordinated complexes of azo ligands, included in different classes with transition metals $(\mathrm{Cu} ; \mathrm{Zn} ; \mathrm{Cr} ; \mathrm{Co} ; \mathrm{Ag}, \mathrm{Cd}$ etc.), are nowadays of interest due to the various and unexpected physical, chemical, photophysical, photochemical and catalytic properties. Some of these compounds are known to be involved in biological reactions (anti-fungal diseases, antioxidant activity, DNA affinity) [12-14], in high density optical data storage, due to their good light and thermal stability properties $[15,16]$, in solar cells and photo sensitizers $[17,18]$. Potentiometric and spectrophotometric studies of $\mathrm{Co}(\mathrm{II}), \mathrm{Ni}$ (II) and $\mathrm{Cu}$ (II) chelates with azo dyes have been also reported [19]. In all fields mentioned above, where these products may be used, their color represents a very important property. Numerical expression of color is greatly superior to verbal specifications [20-24], that is why color study using the CIEL*a* $\mathrm{b}^{*}$ color space approach is opportune to differentiate a ligand from its complex. Considering the importance of the complex dyes, this paper presents the synthesis, the characterization, and the color properties of a new copper complex, using Amido black 10B, an azo acid dye, as ligand.

\section{Materials and methods}

\subsection{Materials. Synthesis of the complex}

All chemicals used in this synthesis were of the analytical grade and were provided by Colorom S.A., S.C. Chimreactiv S.R.L. and Analyticals Carlo Erba.

The $\mathrm{Cu}$ (II) chloride $(0.0039 \mathrm{~mol})$ in a mixture of ethanol: water $(1: 1)(100 \mathrm{~mL})$ was added to the solution of the acid azo dye $(0.006 \mathrm{~mol})$ previously dissolved in the same solvent mixture $(200 \mathrm{~mL})$. The complex precipitated after stirring the solutions under reflux for $0.5 \mathrm{~h}$. The resulting compound was removed by filtration, washed with 1:1 ethanol/water, acetone and dried. The compound was purified by recrystallization from $\mathrm{N}, \mathrm{N}$-dimethylformamide.

\subsection{Methods}

The FT/IR spectra of the complex and the azo dye used as ligand were recorded on a Perkin Elmer-Spectrum 100 spectrometer in the range 4000-650 $\mathrm{cm}^{-1}$ using the UATR technique.

Electronic absorption spectra (UV-Vis) of the complex in N,N-dimethylformamide, and the ligand in water $\left(\mathrm{c}=1.0 \times 10^{-5} \mathrm{~mol} / \mathrm{dm}^{3}\right)$ were performed on a CECIL CE 7200 spectrophotometer in the range $300-800 \mathrm{~nm}$.

For copper content determination in complex the digestion of the sample was first applied, using Digesdahl® Digestion Apparatus, model 23130-18 (HACH). For the complex two parallel samples were digested as follows: approximately $20 \mathrm{mg}$ of samples were weighted and transferred into a 100 $\mathrm{ml}$ Digesdahl digestion flask. Then $4 \mathrm{~mL}$ of concentrated sulfuric acid were added and the temperature was set at $440^{\circ} \mathrm{C}$. After reaching this temperature the water to the aspirator was turned on and $16.7 \mathrm{~mL}$ of $32 \%$ hydrogen peroxide were added into the digestion flask. After the digestion of the samples, the copper content was determined by SensAA flame atomic absorption spectrometer (GBC Scientific Equipment) equipped with a hollow cathode lamp, wavelength $324.7 \mathrm{~nm}$, slit width 0.5 , and integration time $3 \mathrm{~s}$. The flame used was an acetylene-air mixture. Three absorbance values were recorded and the average absorbance value was further used. Four reference standard solutions of copper were prepared in the range of $1-5 \mu \mathrm{g} / \mathrm{mL}$. The absorbance for the standard solutions was measured at $324.7 \mathrm{~nm}$, using the background correction technique. From these values the calibration graph was plotted. The digested samples were aspirated in the acetylene-air flame and the absorbance values were recorded. 
TG/DTA measurements were performed on a Perkin- Elmer DIAMOND thermo-balance for obtaining simultaneously the TG, DTG and HF curves. The experiments were carried out using about $8 \mathrm{mg}$ of sample (ligand and complex), which was weighted into an open aluminium crucible. The furnace temperature was programmed to rise under non-isothermal conditions from ambient temperature to $500^{\circ} \mathrm{C}$ linearly at a heating rate of $10{ }^{\circ} \mathrm{C} / \mathrm{min}$. The experiments were completed in air atmosphere at a flow rate of $100 \mathrm{~mL} / \mathrm{min}$ and nitrogen gas of high purity (C 99.999\%) with a flow rate of $100 \mathrm{~mL} / \mathrm{min}$.

Powder X-ray diffraction (XRD) patterns of the complex was collected by a PANalytical X'pert Pro diffractometer using $\mathrm{Cu}-\mathrm{K} \alpha$ radiation with $(\lambda=1.5418 \AA)$, in the range $2 \theta=5-50^{\circ}$.

The colorimetric analysis was recorded for the D65 (natural light), A (incandescent light), and F2 (fluorescent light) illuminants, under $10^{\circ}$ observer angle, using a Cary-Varian 300 Bio UV-Vis colorimeter with integrating sphere and a Spectralon standard. All color data were expressed by $L^{*}, a^{*}$, $b^{*}$ coordinates, where $L^{*}$ corresponds to lightness; $a^{*}$ corresponds to the transition from green $\left(-a^{*}\right)$ to red $\left(+a^{*}\right)$; and $b^{*}$ corresponds to the transition from blue $\left(-b^{*}\right)$ to yellow $\left(+b^{*}\right)$.

\section{Results and discussions}

The azo acid dye Amido Black 10B (C.I. 20.470) used as ligand with the structure shown in Figure 1 underwent complexation reaction with $\mathrm{Cu}$ (II) ions, using a metal: ligand $=1: 2$ molar ratio. It can be easily observed that only the atoms of the $-\mathrm{OH}$ functional group are involved in the coordination reaction. The structure of the new azo complex dye is presented in Figure 2.<smiles>COc1cc2cc(O)c(N=Nc3ccccc3)c(N)c2c(O)c1N=Nc1ccc(O)cc1</smiles>

Figure 1. Structure of the ligand

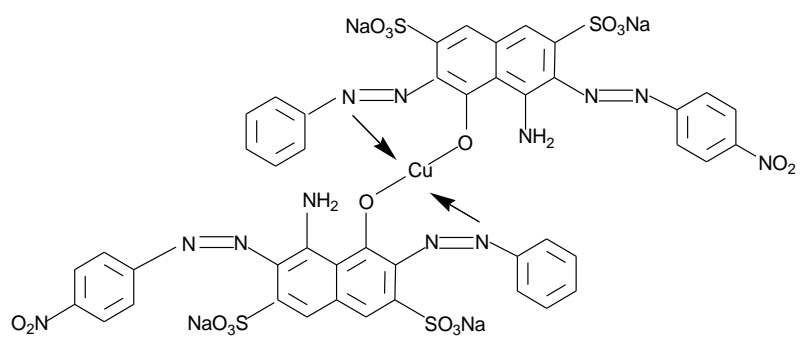

Figure 2. Structure of the complex

\subsection{Atomic absorption spectroscopy}

The copper in complex was determined by the atomic absorption spectroscopy (Table 1) [25].

Table 1. Copper measurements by atomic absorption spectroscopy for copper complex

\begin{tabular}{|c|c|c|c|c|}
\hline Complex & Sample & Sample weight (g) & $\begin{array}{r}\text { Cu (calculated from the proposed } \\
\text { structure), \% }\end{array}$ & Cu (found), \% \\
\hline \multirow{2}{*}{ Complex } & 1 & 0.023 & 4.91 & 4.85 \\
& 2 & 0.022 & & 4.79 \\
\cline { 2 - 5 } & \multicolumn{3}{|c|}{ Average copper content (\%) } & 4.82 \\
\hline
\end{tabular}




\subsection{UV-Vis spectroscopy}

The UV-Vis spectrum of the acid azo dye (Figure 3) showed two bands between $263 \mathrm{~nm}$ and 368 $\mathrm{nm}$. The first band may be due to the transition of $\pi-\pi^{*}$ in the aromatic ring and the second band is due to $\mathrm{n}-\pi^{*}$ transition of the $\mathrm{N}=\mathrm{N}$ group [26]. The formation of the azo metal complex with $\mathrm{Cu}$ (II) was also confirmed by UV-Vis spectrum.

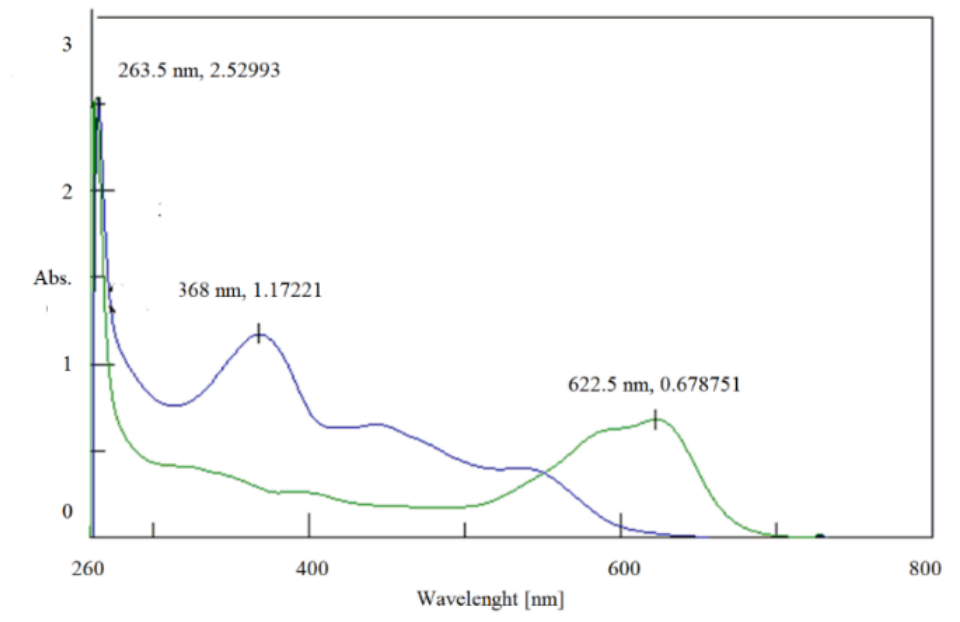

Figure 3. The UV-Vis spectra of the ligand (green line) and the complex (blue line)

It can be seen that $\lambda$ max for the ligand was at $622 \mathrm{~nm}$. The complexation reaction was responsible for a significant hypochromic shift at the $\pi-\pi^{*}$ and $n-\pi^{*}$ transition region, presenting a maximum at $368 \mathrm{~nm}$. The spectrum of $\mathrm{Cu}(\mathrm{II})$ complex shows a broad band in the region 500-600 $\mathrm{nm}$. The position and the shape of this band suggests the merging of three electronic transitions. A square planar geometry was proposed for this complex [27].

\subsection{FT/IR-UATR spectroscopy and Thermal analysis}

The analysis of FT/IR-UATR spectra of the ligand and the complex (figure 4) emphasize the following aspects: the FT/IR spectrum of ligand before thermal treatment reveals characteristic absorption band as a broad signal at $3420 \mathrm{~cm}^{-1}(\mathrm{O}-\mathrm{H}$ stretching from aromatic alcohol groups superposed with the $\mathrm{O}-\mathrm{H}$ stretching from crystallization water) [28]. Absorption bands appear for hydroxyl aromatic group at $1450 \mathrm{~cm}^{-1}-1325 \mathrm{~cm}^{-1}$ and at $850-750 \mathrm{~cm}^{-1}$ spectral range, at $3087 \mathrm{~cm}^{-1}$ for primary amine $\mathrm{N}-\mathrm{H}$ stretching, and at $1650-1600 \mathrm{~cm}^{-1}$, and at $950-900 \mathrm{~cm}^{-1}$ assigned to $\mathrm{C}=\mathrm{C}$ in aromatic di- or trisubstituted compounds in the ligand sample. Within the FT/IR spectrum of the complex one can notice the absence of the $3420 \mathrm{~cm}^{-1}$, and the $826 \mathrm{~cm}^{-1}$ bands characteristic of the aromatic hydroxyl group, indicating that the complexing reaction was carried out on the $\mathrm{OH}$ group. Also, a shift of the characteristic $\mathrm{N}=\mathrm{N}$ bands is observed at higher wavelengths, suggesting that the complex was obtained by bonding to the $\mathrm{N}$ atom [29]. The characteristic aromatic bonding line $\mathrm{C}=\mathrm{C}$ at $1620 \mathrm{~cm}^{-1}$ and $970 \mathrm{~cm}^{-1}$ is shifted to higher wavelengths, also suggesting the formation of the complex as well. The azo $(\mathrm{N}=\mathrm{N})$ group absorption band appears at $1492 \mathrm{~cm}^{-1}$ in the free ligand spectrum, this band being observed having a change in its shape and is shifted to different frequencies in the 1521$1558 \mathrm{~cm}^{-1}$ domain in the complex spectrum; which reveals a bond between the metal ions and the nitrogen atom of the azo group. 


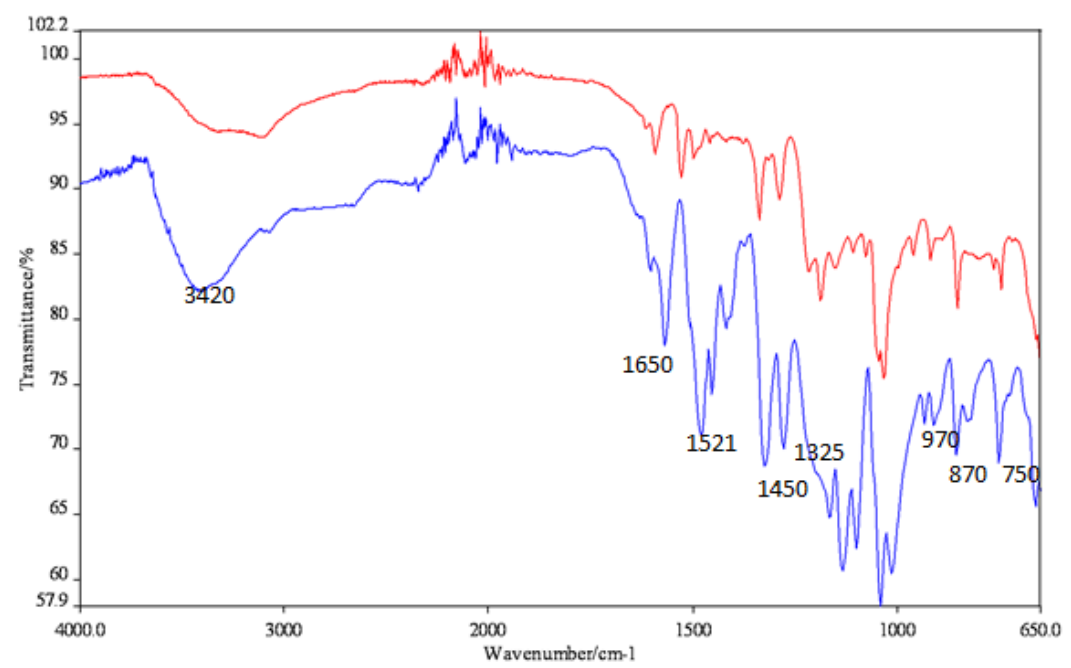

Figure 4. FT/IR spectra of ligand (blue) and complex (red)

The ligand and the complex were thermally treated in the range of $25-500^{\circ} \mathrm{C}$ in the nitrogen atmosphere and in the dynamical air atmosphere, in order to highlight the degradation steps and to observe the thermal-oxidative degradation processes. The residues obtained after thermal treatment at $500^{\circ} \mathrm{C}$ in the air atmosphere and in the nitrogen atmosphere as well, were spectrophotometrically analyzed. The obtained spectra are compared with those of the initial compounds to indicate the bonds that disappear from the spectra (Figures 4-6).

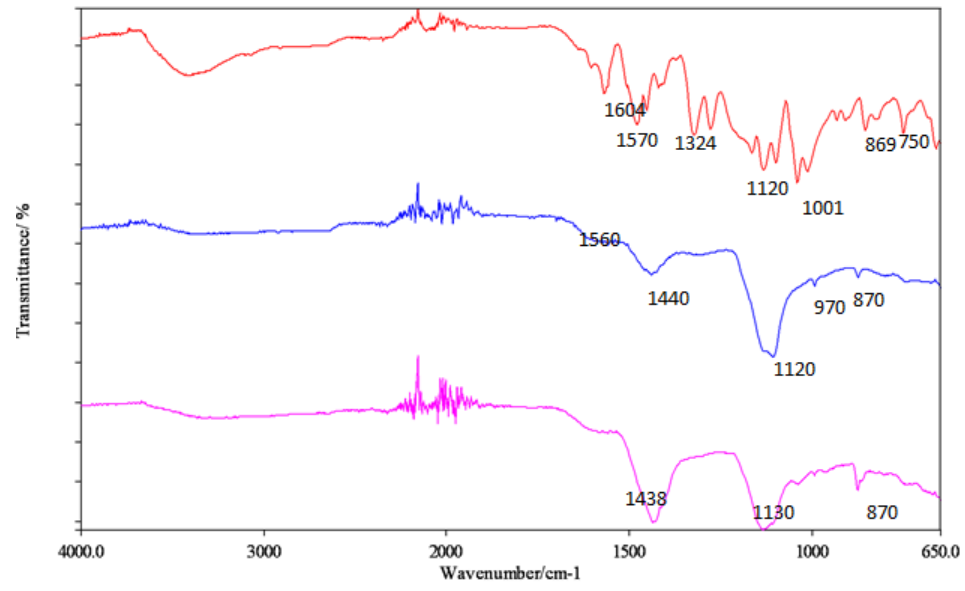

Figure 5. FT/IR spectra of: ligand (red), degraded ligand (blue) in air atmosphere at $500^{\circ} \mathrm{C}$, degraded ligand (violet) in nitrogen atmosphere at $500^{\circ} \mathrm{C}$

It can be observed that the decomposition of the ligand is quite advanced, and that the obtained residues are similar in both air and nitrogen atmospheres at $500^{\circ} \mathrm{C}$, showing that all processes are decomposing ones. The characteristic bands of the $\mathrm{C}=\mathrm{C}$ bond are maintained in the aromatic compounds regions at $1560 \mathrm{~cm}^{1}, 1600 \mathrm{~cm}^{-1}, 996 \mathrm{~cm}^{-1}$, and $860-880 \mathrm{~cm}^{-1}$; and at $1420-1450 \mathrm{~cm}^{-1}$ for the $\mathrm{N}=\mathrm{N}$ bond band (Figure 5).

The degradation of the $\mathrm{Cu}$ (II) complex (Figure 6) is more advanced in the air than in the nitrogen atmosphere at $500^{\circ} \mathrm{C}$. In the air atmosphere, one may notice that the same peaks are found in the ligand and in the complex decomposition. 


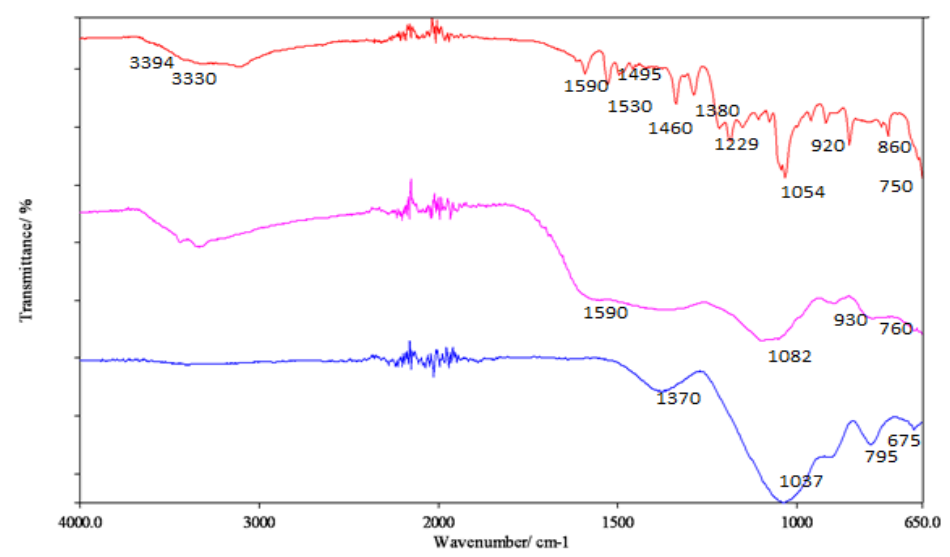

Figure 6. FT/IR spectra of: complex (red), degraded complex (blue) in air atmosphere at $500^{\circ} \mathrm{C}$, degraded complex (violet) in nitrogen atmosphere at $500^{\circ} \mathrm{C}$

The thermal behavior of the ligand (Figure 7) and of the complex (Figure 8) were investigated in air and nitrogen atmosphere by thermal analysis (TG, DTG, Heat Flow) in order to highlight the modifications during heating and the thermodynamic effects that accompany them as well. [30].

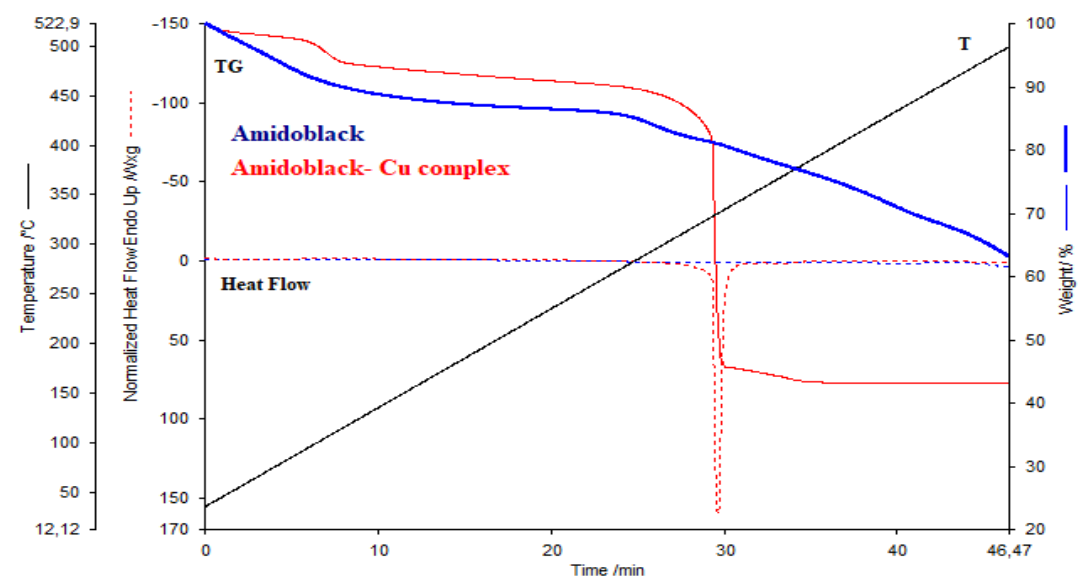

Figure 7. Thermoanalytical curves obtained for the ligand and the complex in air atmosphere with $10^{\circ} \mathrm{C} / \mathrm{min}-500^{\circ} \mathrm{C}$

The thermal degradation of the ligand in the air atmosphere emphasizes several steps of decomposition accompanied by endothermic and exothermic processes. It can be observed the loss of the humidity and crystallization water, in the range of $50-202^{\circ} \mathrm{C}$, followed by the degradation in several steps. During this process, due to the endothermic effect, the crystallization water has a recorded loss of $13 \%$ and there is total loss of mass of $35 \%$. The degradation process is not completed within the studied temperature range, as seen from the spectral analysis performed on the residue obtained at $500^{\circ} \mathrm{C}$ (Table 2 and Figures 7, 8). The thermal degradation of the ligand in the nitrogen atmosphere is similar to the one in the air. 


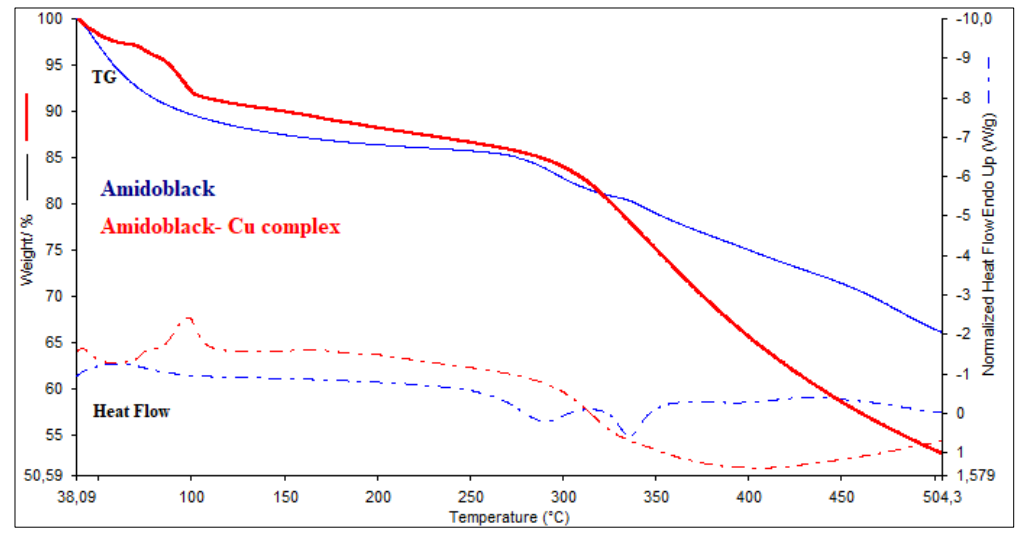

a)

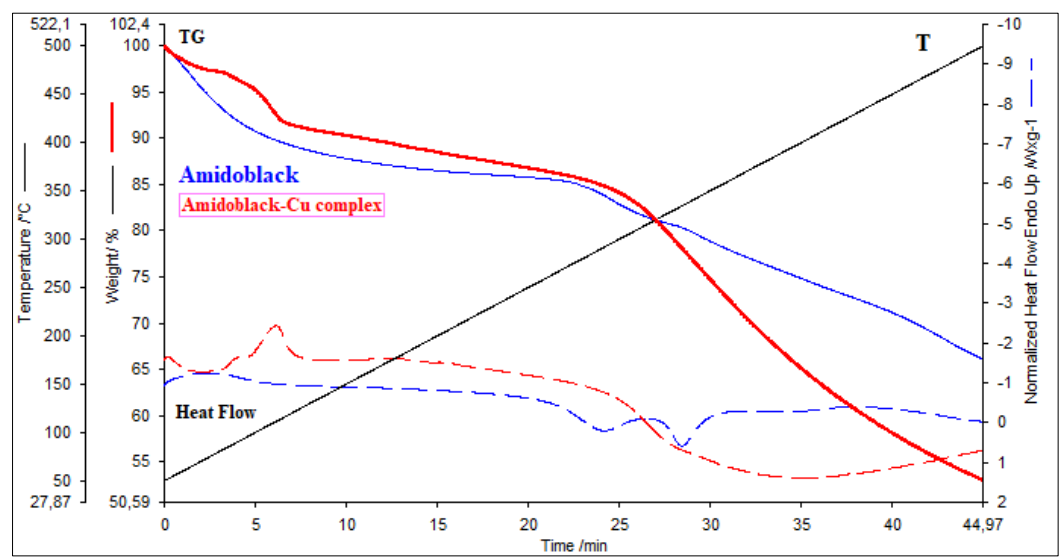

b)

Figure 8. Thermoanalytical curves obtained for the ligand and the complex in nitrogen atmosphere with $10^{\circ} \mathrm{C} / \mathrm{min}-500^{\circ} \mathrm{C}$,

a) dependence with temperature; b) dependence with time

Table 2. Thermoanalytical data obtained for the ligand in air and nitrogen atmospheres with $10^{\circ} \mathrm{c} / \mathrm{min}$

\begin{tabular}{ccccc}
\hline $\begin{array}{c}\text { Compound/ } \\
\text { condition }\end{array}$ & Process & $\mathbf{T}_{\mathbf{i}} /{ }^{\circ} \mathbf{C}$ & $\mathbf{T}_{\mathbf{f}} /{ }^{\circ} \mathbf{C}$ & $\Delta \mathbf{m} \%$ \\
\hline Ligand/air & I & 37 & 150 & 13.23 \\
atmosphere & II & 255 & 324 & 4.5 \\
& III & 324 & 380 & 4.5 \\
\hline Ligand/ nitrogen & I & 38 & 151 & 12.6 \\
atmosphere & II & 249 & 325.5 & 4.85 \\
& III & 326 & 387 & 4.87 \\
\hline
\end{tabular}

Thermogravimetric study of the complex in the air atmosphere and nitrogen atmosphere achieved in $25-500^{\circ} \mathrm{C}$ intervals highlights a completely different behavior. In the air atmosphere, two degradation steps with a loss of $4.13 \%$ from the sample mass represented by the loss of crystallization water and a step in the range $255-306^{\circ} \mathrm{C}$ with a loss of $44 \%$, accompanied by a strong exothermic effect can be observed (Table 3). The decomposition of the complex does not occur above $306^{\circ} \mathrm{C}$. Complexation leads to a destabilization of the ligand structure, which may be explained by the more advanced decomposition in the air atmosphere, in which the last process is attributed to the ligand fragments advanced oxidation. This process is followed by a complete destruction of organic skeletons, and an intense exothermic event on the HF curve can be observed. In the nitrogen atmosphere the thermal analyses highlights the decomposition in several steps, which are difficult to 
separate on thermoanalytic curves. The total mass loss in the studied range is of $45 \%$ of the sample mass (Table 3 and Figures 7, 8).

Table 3. Thermoanalytical data obtained for the complex in air and nitrogen atmospheres with

\begin{tabular}{|c|c|c|c|c|}
\hline \multicolumn{5}{|c|}{$10^{\circ} \mathrm{c} / \mathrm{min}$} \\
\hline $\begin{array}{l}\text { Compound/ } \\
\text { condition }\end{array}$ & Process & $\mathbf{T}_{\mathrm{i}} /{ }^{\circ} \mathbf{C}$ & $\mathbf{T}_{\mathbf{f}} /{ }^{\circ} \mathbf{C}$ & $\Delta \mathrm{m} \%$ \\
\hline $\begin{array}{l}\text { Complex/air } \\
\text { atmosphere }\end{array}$ & $\begin{array}{l}\text { I } \\
\text { II }\end{array}$ & $\begin{array}{c}50 \\
255\end{array}$ & $\begin{array}{c}95 \\
305\end{array}$ & $\begin{array}{c}4.13 \\
43.79\end{array}$ \\
\hline $\begin{array}{l}\text { Complex/ nitrogen } \\
\text { atmosphere }\end{array}$ & $\begin{array}{c}\text { I } \\
\text { II } \\
\text { III }\end{array}$ & $\begin{array}{l}41.6 \\
71.4 \\
266\end{array}$ & $\begin{array}{c}71.4 \\
90.8 \\
491.6\end{array}$ & $\begin{array}{c}4.02 \\
6.2 \\
31.89\end{array}$ \\
\hline
\end{tabular}

The decomposition is not finalized at $500^{\circ} \mathrm{C}$, shown also in the FT/IR spectrum of the residue obtained after thermal treatment (Figure 6). The thermogravimetric analysis and the FT/IR spectral analysis confirmed the obtaining of the complex and its different stability in the air and nitrogen atmosphere.

\subsection{PXRD analysis}

The coper complex shows crystalline structures (Figure 9) [31]. Taking into account this fact and the complex structure of the obtained compound, the existing databases cannot provide more information about it's structure [32].

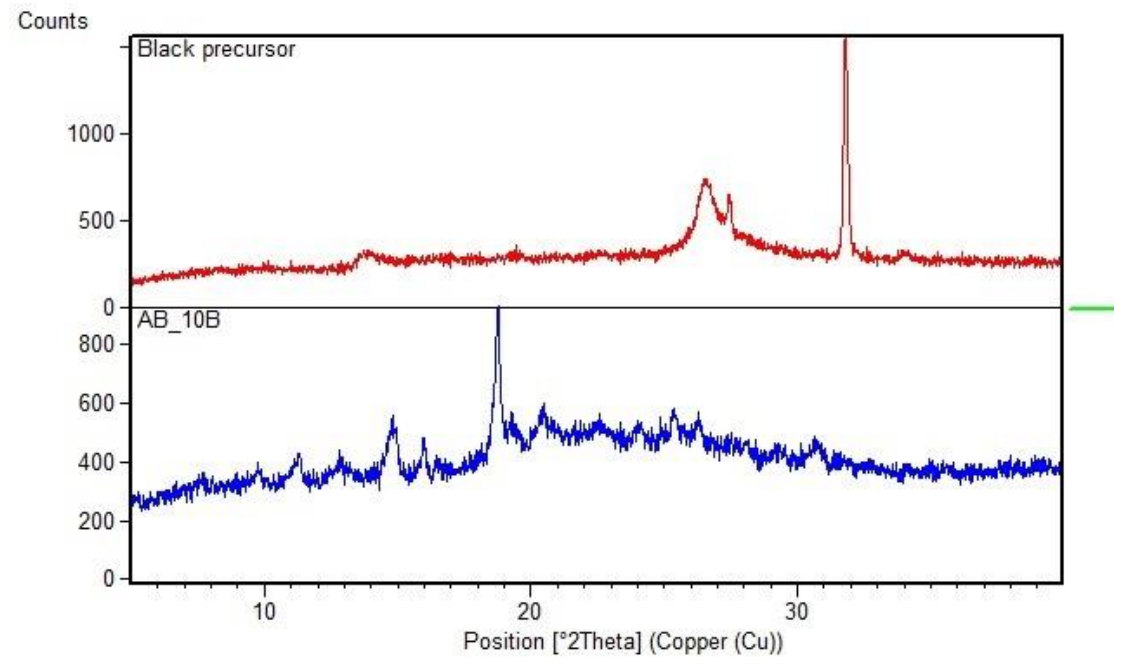

Figure 9. PXRD pattern of the ligand (red) and the copper complex (blue) in powder samples

\subsection{Color analysis}

Compounds color may be definite in the color CIEL*a*b*space [23,24], which is highlighted in this paper for the ligand and the complex in powder.

CIEL*a*b* values of the ligand and its complex for the D65 illuminant (Figure 10) show, an increase of lightness $\left(L^{*}\right)$ value with ligand complexation, and the values of redness $\left(a^{*}\right)$, yellowness $\left(b^{*}\right)$ reflect an orange color of the complex, as compared to the purple color of the ligand. 


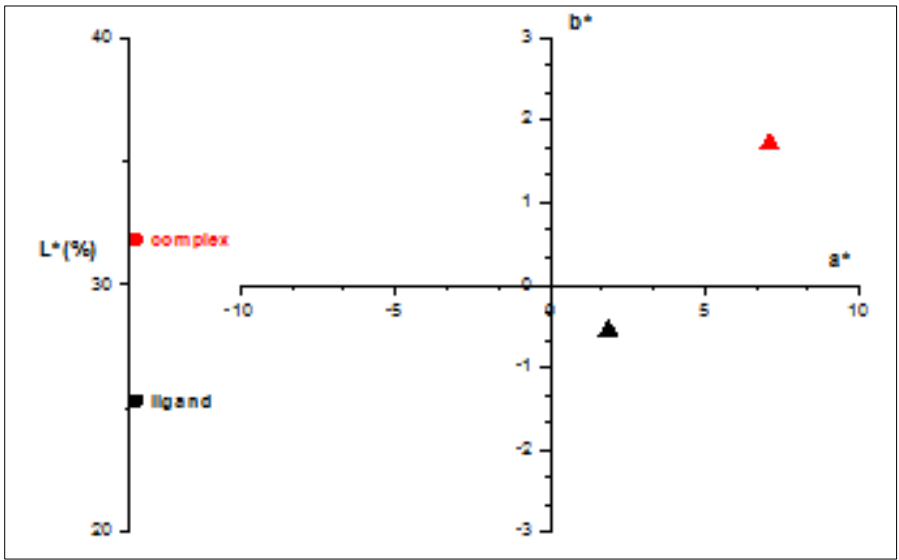

Figure 10. CIEL* $a^{*} b *$ parameters of the ligand and of the complex

The change in color is caused by chelating the copper to hydroxyl and azo major donor groups, which determines a perturbation of the $\pi$-electron distribution, that is, by the attachment of the copper ion to the oxygen of a hydroxyl group, the oxygen lone pair electrons are released more easily into the $\pi$ electron system [20].

As known, two colored surfaces can stimulate all three centers of excitation of the eye to the same extent under a specific illumination but not under a different light source, appearing identical in the first case and different in the second case, the phenomenon being called metamerism [21,22]. This property is highlighted for the complex (Table 4).

The color differences for the D65 illuminant for the complex and the ligand may be calculated. $\Delta E^{*}{ }_{a b}$ (the total color difference, being the geometric distance between two positions in CIEL*a* $\mathrm{b}^{*}$ space, equation (1)), and $\Delta C^{*}$ (the difference in saturation between the complex and the ligand, equation (2)) are important landmarks to compare color properties of different dyes [23,24,33].

Table 4. The color parameters $\left(L^{*}, a^{*}, b^{*}, C^{*}\right)$ of the ligand and the complex at illuminants A, D65, F2

\begin{tabular}{ccccc}
\hline Color parameters & Dye & A & D65 & F2 \\
\hline $\boldsymbol{L}^{*}$ & Ligand & 25.5002 & 25.3183 & 25.4215 \\
& Complex & 33.0576 & 31.8376 & 31.2743 \\
\hline $\boldsymbol{a}^{*}$ & Ligand & 1.6922 & 1.8850 & 1.3148 \\
& Complex & 11.3643 & 7.0989 & 4.0870 \\
\hline $\boldsymbol{b}^{*}$ & Ligand & -0.1101 & -0.5582 & -0.3878 \\
& Complex & 4.5199 & 2.4685 & 1.5870 \\
\hline $\boldsymbol{C}^{*}$ & Ligand & 1.6958 & 1.9660 & 1.3708 \\
& Complex & 12.2302 & 8.2852 & 4.3843 \\
\hline
\end{tabular}

$$
\begin{aligned}
& \Delta E_{a b}^{*}=\sqrt{\left(\Delta L^{*}\right)^{2}+\left(\Delta a^{*}\right)^{2}+\left(\Delta b^{*}\right)^{2}} \\
& \Delta C^{*}=C_{\text {complex }}^{*}-C_{\text {ligand }}^{*}
\end{aligned}
$$

The values of these color differences $\left(\Delta E^{*}{ }_{a b}=8.8\right.$, and $\left.\Delta C^{*}=6.3\right)$ emphasize once again that the color of the complex is different and more intense than that of the ligand.

In the reflectance spectra, the value of white standard reflectance being is 1.00 for all wavelength [22]. The dye color strength in the visible region of the reflectance spectra may be calculated according to the Kubelka-Munk equation (3) [34-36].

$$
K / S=(1-R)^{2} / 2 R
$$


where $R$ represents the reflectance ratio; $K$ - the absorbance coefficient and $S$ - the scattering coefficient.

In concordance to the color properties presented above, it is expected that the complex has a greater color strength than the ligand at a certain wavelength (Figure 11).

The differences between the color strength of the ligand and the complex are higher in the range of 600 to $830 \mathrm{~nm}$ due to the increased stability and saturation via complexation.

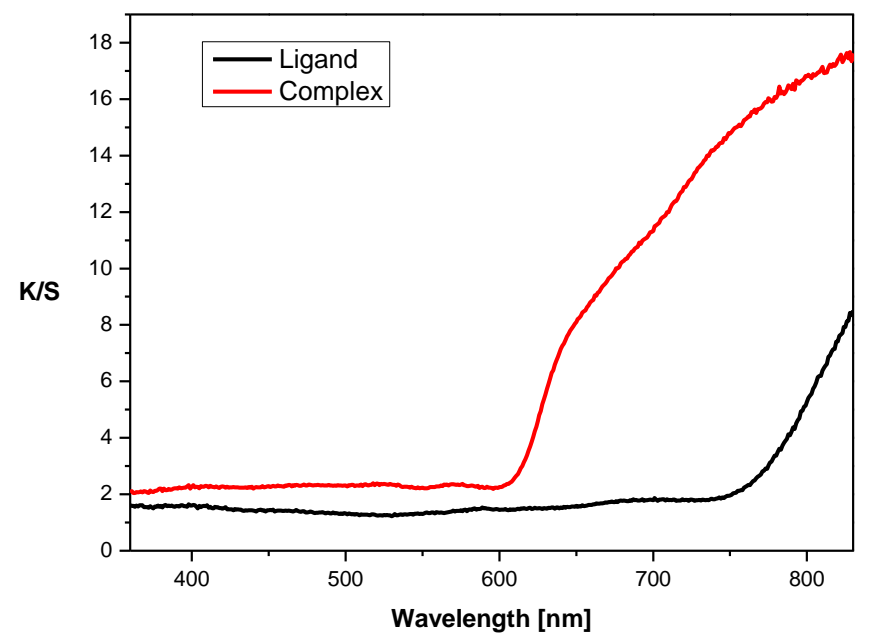

Figure 11. Dependence of the color strength $(K / S)$ on the wavelength of the ligand and of the complex

\section{Conclusions}

The $\mathrm{Cu}$ (II) ion as transition metal and the acid dye Amido black 10B (C.I. 20.470) as ligand were used in the synthesis of a one new complex. The proposed structure for the metal complex was elucidated by physico-chemical methods: FT/IR, UV-Vis, AAs spectroscopy, thermal analysis. Thermogravimetric and spectral analysis of the ligand and the complex confirmed the formation of complex and its different stability in the air and nitrogen atmosphere. The UV-Vis spectra of the ligand and of the complex confirm the formation of a squared planar complex with $\mathrm{Cu}(\mathrm{II})$ with high nitrogen stability. The PXRD analysis shows crystalline structure for the coper complex. The color measurements of the ligand and of the complex in powder were determined using the CIEL* $\mathrm{a}^{*} \mathrm{~b}^{*}$ color space approach, revealing good coloring properties and a small metamerism effect for the complex. Color study reveals important color differences between the ligand and the complex, the ligand being purple and the complex being orange, with superior saturation and color strength.

\section{References}

1.ZOLLINGER, H., Color Chemistry: Synthesis, Properties and Application of Organic Dyes and Pigments, Wiley-VCH, Weinheim, 2003, p.161.

2.MAYNARD, C.W., Riegel's Handbook of Industrial Chemistry, Van Nostard Reinhold, New York, 1983, p. 145.

3.VENKATARAMAN, K.,The Analytical Chemistry of Synthetic Dyes, Wiley Interscience, New York, 1977, p. 403.

4.HASSAN, M.M., BHAGVANDAS, M., Journal of Cleaner Production, 152, 2017, p. 464. DOI.ORG/10.1016/J.JCLEPRO.2017.03.139.

5.GRAD, M.E., SIMU, G.M., MUNTEAN, S.G., ILIA, G, Jornal of Iranian Chemical Society, 10, no.4, 2013, p. 807. DOI.ORG/10.1007/S13738-012-0216-Y. 
6.MOTIEI, H., JAFARI, A., NADERALI, R., Optic\& Laser Technology, 88, 2017, p. 68.

DOI.ORG/10.1016/J.OPTLASTEC.2016.09.011.

7.YAMJALA, K., NAINAR, M.S., RAMISETTI, N.R., Food Chemistry, 192, 2016, p. 813. DOI.ORG 10.1016/J.FOODCHEM.2015.07.085.

8.HARISHA, S., KESHAVAYYA, J., KUMARA SWAMY, B.E., VISWANATH, C.C., Dyes and Pigments, 136, 2017, p. 742. DOI.ORG/10.1016/J.DYEPIG.2016.09.004.

9.TROTMAN, E.R., Dyeing and Chemical Technology of Textile Fibres, Griffin, London, 1970, p. 212.

10.RĂDULESCU-GRAD, M.E., MUNTEAN, S.G., TODEA, A., VREDES, O., Chemical Bulletin of Politehnica University of Timisoara, 60, 2015, p. 37.

11.HUNGER, K., Industrial Dyes; Chemistry, Properties Applications, Wiley-VCH, Weinheim, 2003, p. 7.

12.AL-ADILEE, K., KYHOIESH, H.A.K., Journal of Molecular Structure, 1137, 2017, p. 160, DOI.ORG/.10.1016/J.MOLSTRUC.2017.01.054.

13.GABER, M., EL-SAYED, Y.S., BARADIE, K.Y., FAHMY, R.M., Spectrochim Acta Molcular Biomolcular Spectroscopy, 107, 2013, p. 35, DOI.ORG/10.1016/J.SAA.2013.01.039.

14.SHAHABADY, N., AKBARI, A., JAMSHIDBEIGI, M., NKHODARAHMI, R., Nucleosides Nucleotides and Nucleic Acids, 5, 2016, no.6, .3 p. 15, OI.ORG/10.1080/15257770.2016.1163378.

15.RETZMANN, N., MAATZ, G., RITTER, R., Journal of Organic Chmistry, 10, 2014, p. 2480, DOI.ORG/10, 2480-2483. DOI:10.3762/BJOC.10.259.

16.NEJATI, N., REZVANI, Z., SEYEDAHMADIAN, M., Dyes and Pigments, 83, 2009, p. 304, DOI.ORG/10.1016/J.DYEPIG.2009.05.007

17.HAN, M., ZHANG, X., ZHANG, X., LIAO, C., ZHU, B., LI, Q., Polyhedron, 85, 2015, p. 864, DOI.ORG/10.1016/J.POLY.2014.10.026.

18.ÇAKAR, S., Journal Power Sources, 435, 2019, p. 226825,

DOI.ORG/10.1016/J.JPOWSOUR.2019.22682.

19.EL-BINDARY, A.A., DIAB, M.A., EL-SONBATI, A.Z., SALEM, Q.L., Journal of molecular liquids, 219, 2016, 737, DOI.ORG/10.1016/J.MOLLIQ.2016.04.008.

20.AHN, S.B., KIM, J.P., SHIM, W.S., Fibres and Polymers, 10, 2009, p. 643,

DOI.ORG/10.1007/S12221-010-0643-2.

21.GRIFFITHS, J., Color and Constitution of Organic Molecules, Academic Press Inc., London, 1976, p. 1.

22.MACADAM, D.L., Color Measurement, Springer-Verlag Berlin, Heidelberg, New York, 1981, p. 106.

23.IANOŞ, R., LAZĂU, R., Dyes and Pigment, 105, 2014, p. 152,

DOI.ORG/10.1016/J.DYEPIG.2014.02.007.

24.IANOŞ, R., MUNTEAN, E., PĂCURARIU, C., LAZĂU, R., BANDAS, C., DELINESCU, G., Dyes and Pigments, 142, 2017, p. 24, DOI.ORG/10.1016/J.DYEPIG.2017.03.016.

25.CANTLE, J.E., Atomic Absorption Spectrometry, Elsevier, New York, 1983, p. 343.

26.MAGER, S., Organic Structural Analysis (Analiza Structurala Organica), Editura Ştiinţifică şi Enciclopedică, Bucureşt, 1979, p. 232.

27.LEVER, A.B.P., Inorganic Electronic Spectroscopy, Elsevier, New York, 1968, p. 145.

28.EL-DEEN, I.M., SHOAIR, A.F., EL-BINDARY, M.A., Journal of molecular liquids, 249, 2018, p. 533, DOI.ORG/10.1016/J.MOLLIQ.2018.08.075.

29.MOHAMED, G.G., ZAYED, M.A., EL-GAMEL, N.E.A., Spectrochimica Acta A, 58, 2002, p. 3167, DOI.ORG/10.1016/S1386-1425(02)00122-1.

30.BROWN, M.E., Introduction to Thermal Analysis: Techniques and Applications, Kluwer Academic Publishers, London, 2001, p. 343. 
31.WARREN, B. E. X. Ray Diffraction; Dover Publication, Inc: New York, USA, 1990.

32.GROOM, C.R. BRUNO, I.J., LIGHTFOOT, M.P., WARD, S.C. The Cambridge structural database, Acta Crystallogr.,Sect.B , 2016, 72, 171.

33.CYSEWSKI, P., JELIŃSKI, T., Journal of Molecular Modeling, 19, no.10, 2013, p. 4089, DOI.ORG/10.1007/S00894-012-1717-4.

34.TOUSIROT, M., NOWIK, W., HNAWIA, E., LEBOUVIER, N., HAY, A.E, DE LA SAYETTE, A., DIJOUX-FRANCA, M.G., CARDON, D., NOUR, M., Dyes and Pigments, 102, 2014, p. 102, DOI.ORG/10.1016/J.DYEPIG.2013.11.010.

35.SHAHID, M., AHMAD, A., YUSUF, M., KHAN, M.I., KHAN, S.A., MANZOOR, N., MOHAMMAD, F., Dyes and Pigments, 95, no.1, 2012, p.53.

DOI.ORG/10.1016/J.DYEPIG.2012.03.029.

36.BHATE, P.M., DEVI, R.V., DUGANE, R., HANDE, P.R., SHAIKH, L., VAIDYA, S., MASAND, S., Dyes and Pigments, 145, 2017, p. 208, DOI.ORG/10.1016/J.DYEPIG.2017.06.007

$\overline{\text { Manuscript received: } 17.02 .2020}$ 